\title{
Comparison between continuous and intermittent ozonation for remediation of soils contaminated with polycyclic aromatic hydrocarbons
}

\author{
J. Wu $\cdot$ Y. Jiang $\cdot$ Z. Ye $\cdot$ M. Prabhakar $\cdot$ \\ R. Yu $\cdot$ H. Zhou
}

Received: 19 March 2014/Revised: 5 November 2014/ Accepted: 18 January 2015/Published online: 4 February 2015

(C) Islamic Azad University (IAU) 2015

\begin{abstract}
Continuous ozonation can inactivate indigenous microbes due to the disinfection capability of ozone, which may affect subsequent bioremediation of soils. This study investigated the efficiency of removing polycyclic aromatic hydrocarbons from soils using intermittent ozonation technique, where ozone was sparged through the soil column every alternate day, resulting in shorter ozonation time for each ozonation circulation than continuous ozonation. The results showed that $85 \%$ Phe, $94 \%$ Ant, $76 \%$ Flu, $87 \% \mathrm{Pyr}$, and $91 \% \mathrm{BaP}$ were removed on 32 days in continuous ozonation treatment, while $90 \%$ Phe, $84 \%$ Ant, $78 \%$ Flu, $81 \%$ Pyr, and $96 \%$ BaP were removed on 32 days in intermittent ozonation treatment, indicating both intermittent ozonation and continuous ozonation can effectively remove polycyclic aromatic hydrocarbons from soils. Fluorescein diacetate hydrolysis results indicated that the total microbial activity of intermittent ozonation was significantly $(p<0.05)$ higher than that of continuous ozonation treatment at $8,16,24$, and 32 days. The toxicity bioassay of soil extracts showed that the relative luminescence increased from 5 to $30 \%$ at 8 days, without significant $(p>0.05)$ increase at 32 days in continuous ozonation treatment, while it increased to $61 \%$ at 32 days in intermittent ozonation treatment, indicating intermittent ozonation was more effective than continuous ozonation for the detoxification of soils contaminated with polycyclic aromatic hydrocarbons. It suggested that both treatments were equally effective at removing polycyclic aromatic hydrocarbons from soil, but
\end{abstract}

J. Wu $\cdot$ Y. Jiang $\cdot$ Z. Ye $\cdot$ M. Prabhakar $\cdot$ R. Yu $\cdot$ H. Zhou $(\bowtie)$ Department of Environmental Health Science, School of Public Health and Tropical Medicine, Southern Medical University, Guangzhou 510515, People's Republic of China e-mail: biodegradation@gmail.com intermittent ozonation was better than continuous ozonation for further detoxification and maintaining the total microbial activity of soil.

Keywords Soil pollution - Soil remediation - Ozone · Detoxification · Microbial activity

\section{Introduction}

Polycyclic aromatic hydrocarbons (PAHs) pose an important environmental and health threat because of their toxicities to various organisms and their potential mutagenic and carcinogenic effects on humans (Haritash and Kaushik 2009). Petroleum products are the major source of PAHs. PAH contamination in soils is widespread as gasoline and fuel oil spills are common (Masten and Davies 1997). Thus, it is necessary to develop an effective technique for the remediation of soils contaminated with PAHs.

Ozone is an unstable and a high-potential oxidant capable of oxidizing a variety of recalcitrant organic pollutants (Giri et al., 2008; El Diwani et al. 2009; Gharbani et al. 2010); thus, it has been widely used. Ozone reacted with PAHs by bond attack to produce the quinone or hydroxyl functional groups and by atom attack to cause ring cleavage resulting in phenyl-naphthyl-type products (Yao et al. 1998a, b). Ozonation has been established as a promising approach for the remediation of PAH-contaminated soils under unsaturated or saturated conditions (Eberius et al. 1997; Masten and Davies 1997; Goi and Trapido 2004; Goi et al. 2006; Hong et al. 2008; Luster-Teasley et al. 2009; Rivas et al. 2009). Furthermore, several field sites contaminated with petroleum were successfully remediated using in situ ozone sparging system (Nimmer et al. 2000). 
Some studies indicated that ozonation could increase the biodegradability of recalcitrant pollutants (Lopez et al. 1998) and could be combined with biological treatment to improve the remediation of contaminated soils (Haapea and Tuhkanen 2006; Derudi et al. 2007). However, in situ continuous ozonation can inactivate the indigenous microbes of soils because of the disinfectant property of ozone. A number of indigenous microbes in the soils, including heterotrophic, alkane-degrading, and phenanthrene-degrading bacteria, were exponentially reduced by more than four orders of magnitude after $900 \mathrm{~min}$ of continuous ozonation (Ahn et al. 2005; Jung et al. 2005). The total number of microbial functional genes pertaining to carbon, nitrogen, and sulfur cycling and organic contaminant degradation and the overall genetic diversity in crude oil-contaminated soils significantly decreased after continuous ozonation treatment (Liang et al. 2009). The decrease in the indigenous microbial population and functional genes must greatly affect the subsequent bioremediation and element cycling of soils.

Previous studies on the remediation of soils using ozone were conducted using continuous ozonation under for a long processing time ( $>3 \mathrm{~h}$ ), sufficient to inactivate indigenous microbes and decrease their population. An intermittent ozonation technique, where ozone is intermittently sparged through soils, shortens the processing time of each ozone circulation and alleviates the disinfection effect on the indigenous microbes in the soils. However, little is known about the effect of intermittent ozonation on the removal of soil pollutants, detoxification, and microbial activity of soil microorganisms. The present study investigated comparatively the remediation and the detoxification efficiency of intermittent and continuous ozonation treatments as well as the change of total microbial activity of soil microbes in PAH-contaminated soils. The research work was carried out in Southern Medical University in the period of May 2010 to October 2011.

\section{Materials and methods}

\section{Chemicals}

Phenanthrene (Phe) (purity: $98 \%$ ), fluoranthene (Flu) (purity: $98 \%$ ), anthracene (Ant) (purity: $99 \%$ ), pyrene (Pyr) (purity: $98 \%$ ), and m-terphenyl (purity: $99 \%$ ) were from Aldrich. Benzo(a)pyrene (BaP) (purity: $>96 \%$ ) was from Fluka. Fluorescein diacetate (FDA) was from Sigma. A $500 \mu \mathrm{g} \mathrm{mL}^{-1} \mathrm{~m}$-terphenyl, used as internal standard, was prepared in acetone. The luminescent bacteria Vibrio qinghaiensis sp.-Q67 kit was purchased from Beijing Hamamatsu Photo Techniques, China.
Soil preparation and PAH spiking

The soil samples were collected in 2-mm sieves from 2 to $10 \mathrm{~cm}$ depth of the soil surface at Southern Medical University campus, Guangzhou, China. Fifty milliliters of acetone containing $150 \mathrm{mg}$ each of Phe, Ant, Flu, and Pyr and $75 \mathrm{mg} \mathrm{BaP}$ was spiked to $1.5 \mathrm{~kg}$ soil and thoroughly mixed to get the homogenous mixture. The solvent was allowed to evaporate in a fume hood. BaP was spiked at half level of the other PAHs, due to the abundance of PAHs in environment is different, and high molecular weight PAHs are generally lower abundant than light molecular weight PAHs in soils. Since $\mathrm{BaP}$ is a human carcinogen, we rationally reduce $\mathrm{BaP}$ consumption in laboratory without influencing experiments.

\section{Measurement of soil physical and chemical properties}

The soil properties, including water content, $\mathrm{pH}$, soil organic matter (SOM), and soil texture, were determined according to National Standard Method GB 7172-1987, NY/T 1377-2007, GB 9834-1988, and the pipette method (Gee and Bauder 1986), respectively. The characteristics of the soils are listed in Table 1.

\section{Ozonation of soil}

The concentration of the ozone gas produced from ambient air using a 990-B Ozonizer was detected as $4 \mathrm{mg} \mathrm{L}^{-1}$ using photometric method (Rakness et al. 1996). Gaseous ozone was sparged at a flow rate of $20 \mathrm{~mL} \mathrm{~s}^{-1}$ through a glass column (length: $25 \mathrm{~cm}$ and internal diameter: $3 \mathrm{~cm}$ ) containing $150 \mathrm{~g}$ of PAH-spiked soils using a gas dispenser. In continuous ozonation treatment, the soils were continuously treated for $180 \mathrm{~min}$ where as in intermittent ozonation treatment the soils were treated for 12 min every alternate day for a period of 32 days (stopped when the total ozonation time was equal to $180 \mathrm{~min}$ ). After ozonation, the glass columns containing PAH-spiked soils were incubated in a biochemical incubator (Jiangsu Jiangfen Electroanalytical Instrument, China) at $25{ }^{\circ} \mathrm{C}$ for 32 days. About $10 \mathrm{~g}$ soils collected from the column every 8 days was used to measure the total microbial activity freshly or stored at $-20{ }^{\circ} \mathrm{C}$ for PAH detection until use.

Table 1 Characteristics of soils $(n=3)$

\begin{tabular}{llllll}
\hline $\begin{array}{l}\text { Water } \\
\text { content }(\%)\end{array}$ & PH & SOM (\%) & \multicolumn{2}{l}{ Texture (\%) } \\
\cline { 3 - 5 } & & & Sand & Silt & Clay \\
\hline $8.20 \pm$ & $7.97 \pm$ & $8.04 \pm$ & $56.26 \pm$ & $38.32 \pm$ & $5.42 \pm$ \\
1.09 & 0.07 & 1.31 & 3.08 & 3.43 & 1.94 \\
\hline
\end{tabular}


Enumeration of total microbial activity in soil

The total microbial activity of soil was determined from hydrolysis of FDA using the procedure described by Schnürer and Rosswall (1982). Autoclaved soil was used as control sample. Briefly, $2 \mathrm{~g}$ soil was added along with FDA (final concentration, $10 \mu \mathrm{g} \mathrm{mL}^{-1}$ ) to a glass flask filled with $50 \mathrm{~mL}$ sterile sodium phosphate buffer $(60 \mathrm{mM}, \mathrm{pH}$ 7.6), and the mixture was incubated at $24^{\circ} \mathrm{C}$ for $2 \mathrm{~h}$ on a rotary shaker. FDA hydrolysis was terminated by adding $50 \mathrm{~mL}$ of acetone. Soil was removed from the incubated solution by centrifugation for $5 \mathrm{~min}$ at $6,000 \mathrm{rpm}$. The supernatant was filtered with $0.45-\mu \mathrm{m}$ syringe filter (TPP, Europe/Switzerland), and the filtrate was used for measuring the absorbance at $490 \mathrm{~nm}\left(\mathrm{~A}_{490}\right)$ by spectrophotometry (Infinite M200, TECAN). Every treatment was done in triplicate.

\section{PAH extraction}

PAHs were extracted from soil as described previously (Nam and Kukor 2000; Sung et al. 2008). A $10 \mathrm{~mL}$ extraction solvent (dichloromethane: acetone $=1: 1 \mathrm{v} / \mathrm{v}$ ) was added to the stoppered flask containing each $1 \mathrm{gm}$ of soil sample and anhydrous sodium sulfate. The slurry was shaken $(100 \mathrm{rpm})$ at $25^{\circ} \mathrm{C}$ for $48 \mathrm{~h}$ for $\mathrm{PAH}$ extraction. The slurry was transferred to $50 \mathrm{~mL}$ glass tube, and the flask was washed twice with $5 \mathrm{~mL}$ of extraction solvent. The solvents were combined and concentrated to $10 \mathrm{~mL}$ using an evaporator for further analysis. The extraction recoveries of PAHs spiked to soils $\left(25,50\right.$, and $\left.100 \mu \mathrm{g} \mathrm{g}^{-1}\right)$ ranged from $82.3 \pm 4.2$ to $101.5 \pm 5.3 \%$.

Gas chromatography-mass spectrometry (GC-MS) analysis

An amount of $1 \mathrm{~mL}$ of the extract was passed through a $0.45-\mu \mathrm{m}$ syringe filter to remove any particulates present. A $10 \mu \mathrm{L}$ of m-terphenyl $\left(500 \mu \mathrm{g} \mathrm{mL}^{-1}\right)$ was injected to $1 \mathrm{~mL}$ of the extract and used as internal standard. The samples were analyzed by GC-MS (Agilent 6890-5973N) equipped with an HP-5 MS capillary column $(30 \mathrm{~m}$ length $\times 0.25 \mathrm{~mm}$ internal diameter $\times 0.25 \mu \mathrm{m}$ thickness). Helium was used as the carrier gas at a constant flow rate of $1 \mathrm{~mL} \mathrm{~min}{ }^{-1}$. The $\mathrm{MS}$ interface temperature was $280{ }^{\circ} \mathrm{C}$, and the ion source temperature was $230{ }^{\circ} \mathrm{C}$. The oven temperature program was set as follows: The initial temperature of $80{ }^{\circ} \mathrm{C}$ was ramped to $300{ }^{\circ} \mathrm{C}$ at $10^{\circ} \mathrm{C}$ $\min ^{-1}$ and held for $5 \mathrm{~min}$. An amount of $1 \mu \mathrm{L}$ of the extract was injected in splitless mode. The samples were then run in selective ion mode.
Toxicity assay

The acute toxicities of the soil extracts were tested by the luminescent assay of $V$. qinghaiensis sp.-Q67 kit in accordance with our previous method (Wu et al. 2010). The toxicity assays were performed in triplicates.

Statistical analysis

The differences between treatments were analyzed by $t$ test (a $p$ value $<0.05$ was considered statistically significant), using the SAS software (SAS Institute, Cary, NC, USA).

\section{Results and discussion}

Removal of PAHs

As shown in Fig. 1b, $85 \%$ Phe, $94 \%$ Ant, $76 \%$ Flu, $87 \%$ Pyr, and $91 \% \mathrm{BaP}$ were removed in 32 days in continuous ozonation treatment, while $90 \%$ Phe, $84 \%$ Ant, $78 \%$ Flu, $81 \%$ Pyr, and $96 \%$ BaP were removed in 32 days in intermittent ozonation treatment (Fig. 1c).

Toxicity assay

As shown in Fig. 2, $95 \%$ of bacterial luminescence was inhibited by the extracts from PAH-contaminated soil. After continuous ozonation treatment, the relative luminescence increased from 5 to $30 \%$ on 8 days, and it did not increase significantly $(p>0.05)$ in the following period from 8 to 32 days. After intermittent ozonation treatment, the relative luminescence increased to 13,24 , $52,61 \%$ on $8,16,24$, and 32 day, respectively. The results indicated that intermittent ozonation was more effective than continuous ozonation in the detoxification of soils contaminated with PAHs at the end of treatments.

Change in the total microbial activity of soil microorganisms

The total microbial activity of soil microorganisms was evaluated by FDA hydrolysis. FDA hydrolysis in continuous ozonation-treated soil declined significantly $(p<0.05)$ after $3 \mathrm{~h}$ of ozonation and slightly increased in the following experimental days 8, 16, 24, and 32 days. However, it was still significantly $(p<0.05)$ lower than that in intermittent ozonation-treated soil on $8,16,24$, and 32 days (Fig. 3), respectively, indicating that intermittent ozonation-treated soil has a higher total soil activity of microorganisms than continuous ozonation-treated soil. 
Fig. 1 Removal of PAHs from soil by ozonation: a control without ozonation, $\mathbf{b}$ continuous ozonation treatment, and c intermittent ozonation. The inset is the change in PAHs as a function of continuous ozonation time. Error bars represent one standard deviation $(n=3)$
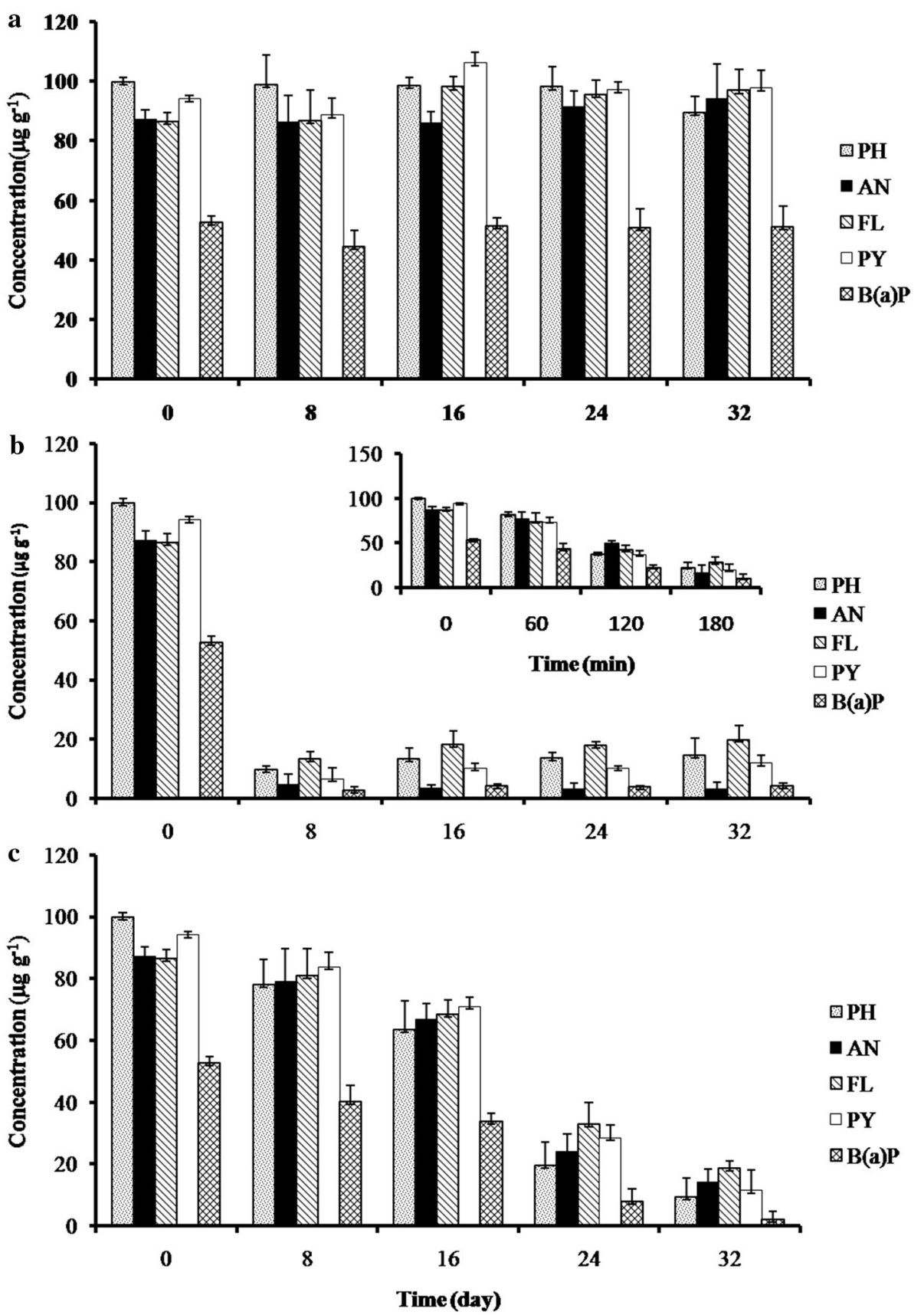

Ozonation is a promising approach for the remediation of soils contaminated with organic compounds. The reaction between ozone and soils contaminated with organic compounds is very complicated and obeys different kinetics. The ozone decomposition rate in soil water is first order regarding gaseous ozone concentration, and the reaction rate between ozone and soil matrix is second order, while the removal of PAH experiences pseudo-first-order kinetics (Hsu and Masten 1997). Ozone concentration exerts a slight positive effect, but difficult to increase PAH removal efficiency when high ozone concentrations are used (Rivas et al. 2009). In addition, soil characteristics would affect the remediation efficiency of ozonation. Previous studies showed that soil moisture content results in a reduction in the extent of contaminant degradation due to the reaction of ozone with soil moisture (Yu et al. 2005), and higher SOM depletes ozone and affects the transport of gaseous ozone (Jung and Choi 2003), which influence the contaminant degradation in soils. In the present study, the soils were characterized as low water, low SOM (Table 1), which would benefit PAH degradation by ozonation. Similar results were seen in previous studies (Eberius et al. 1997; Masten and Davies 1997; Goi and Trapido 2004; Hong et al. 2008; Luster-Teasley et al. 2009; Rivas et al. 2009). 


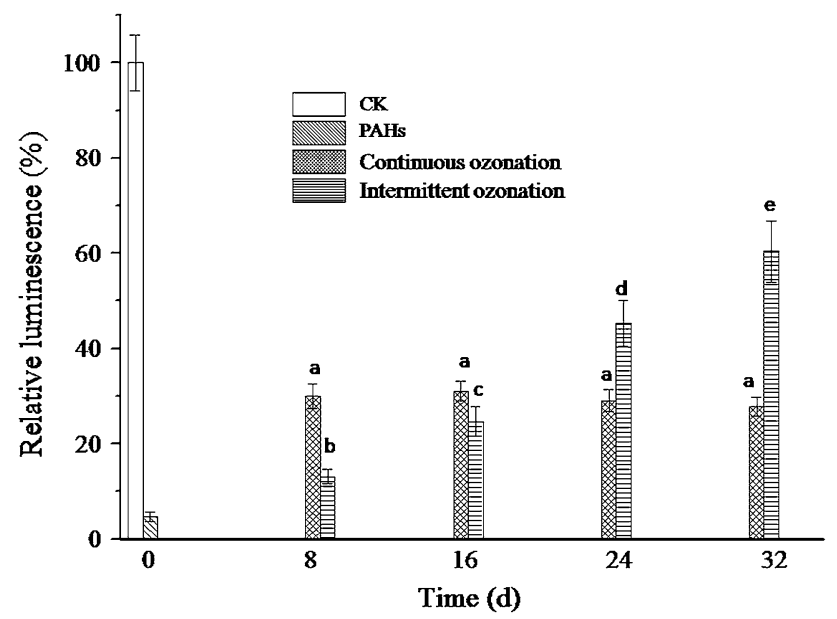

Fig. 2 Change of the toxicity of the soils after ozonation. The lowercase letter a represents no significant difference $(p>0.5)$ between continuous ozonation treatments, whereas the lowercase letters $b, c, d$, and $e$ represent significant difference $(p<0.5)$ between intermittent ozonation treatments. The different lowercase letters ab, ac, ad, and ae represent significant difference $(p<0.5)$ between continuous and intermittent ozonation at 8, 16, 24, and 32 days, respectively. Error bars represent one standard derivation $(n=3)$

In soils, ozone can be readily decomposed upon reacting SOM and metal oxide to produce $\mathrm{OH}$ radical (Choi et al. 2002; Jung and Choi 2003), which is a powerful, effective, nonspecific oxidizing agent. Hence, both ozone and its decomposed product $\mathrm{OH}$ radicals can readily react with PAHs. The possible mechanism of PAH ozonation in soil is that the PAHs react with ozone by bond attack to produce the quinone or hydroxyl functional groups and by atom attack to cause ring cleavage resulting in phenyl-naphthyltype products (Yao et al. 1998a, b).

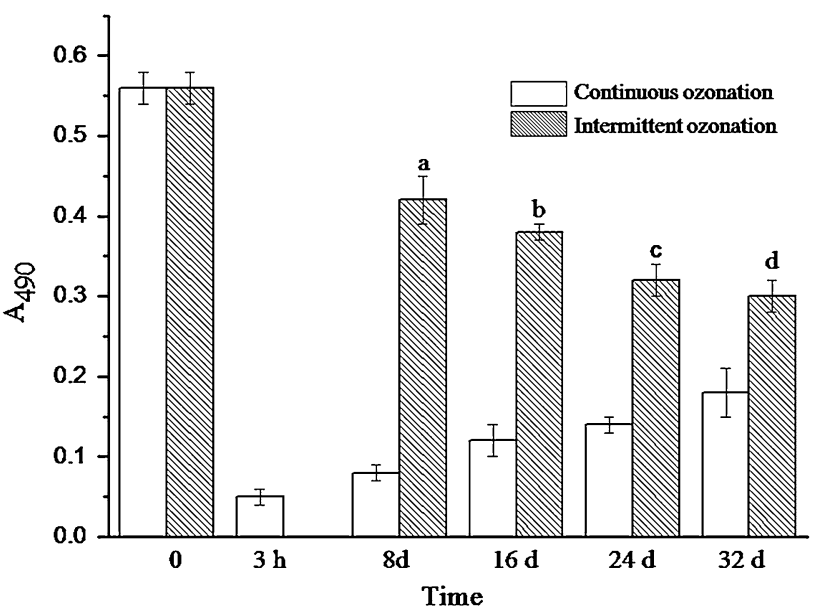

Fig. 3 Change of the total microbial activity of soil microorganisms. The lowercase little $a, b, c$, and $d$ represent significant difference $(p<0.5)$ between continuous and intermittent ozonation treatments at 8, 16, 24, and 32 days, respectively. Error bars represent one standard derivation $(n=3) . h$ hour, $d$ day
Ozonation may not mineralize the target compounds completely, but transform to by-products (Jekel 2000). PAHs are very reactive to ozone and form by-products constituting oxygenated species of the parent compound (mainly ketones, aldehydes, and carboxylic acids) (Yao et al. 1998a, b; Rivas et al. 2000). Thus, the toxicities of the ozonation by-products need to be afforded concern. In the present study, the bacterial luminescence bioassay data indicated that both continuous and intermittent ozonation treatments can significantly $(p<0.01)$ detoxify soils contaminated with PAHs, whereas intermittent ozonation treatment is more effective than continuous ozonation treatment in detoxification (Fig. 2). The difference in detoxification between continuous and intermittent ozonation treatments might have resulted from the difference in the inactive effect on indigenous microbes (Fig. 3). As ozone is a disinfectant, continuous ozonation treatment may have exponentially inactivated the indigenous microbes and microbial functional genes (Ahn et al. 2005; Jung et al. 2005; Liang et al. 2009). The decline of microbial activity of soil microorganisms must have greatly affected subsequent biodegradation and detoxification of the PAH by-products since the by-products are readily biodegradable by indigenous microbes of soils (Nam and Kukor 2000; Zeng et al. 2000). The intermittent ozonation approach has a shorter processing time of each ozone circulation, which might have presented lesser effect on the indigenous microbes of the soils (Fig. 3), thus benefiting from subsequent biodegradation and detoxification of soils. Russo et al. (2012) also found that a short ozonation treatment $(10 \mathrm{~min})$ showed a high potential to overcome the limitation of bioremediation of $\mathrm{BaP}$ and to decrease toxicity of soils. Of course, a further research that monitor the biodegradation of the PAH by-products both in continuous and intermittent ozonation treatments is needed to better illustrate the value of maintaining the bacterial activities of soils.

The major disadvantage of intermittent ozonation is the long operation time. As shown in Fig. 1, PAH concentrations were significantly decreased within $3 \mathrm{~h}$ in continuous ozonation treatment, but it took 32 days in intermittent ozonation treatment. However, intermittent ozonation treatment could take more advantages of the activities of indigenous microbes than continuous ozonation in the remediation of soils contaminated with PAHs. Without consideration of time cost, intermittent ozonation treatment was proved to be a suitable alternative method to continuous ozonation treatment for the remediation of soils contaminated with PAHs in practices.

In summary, our study suggested that both intermittent and continuous ozonation treatments were equally effective at removing PAHs from soil, but intermittent ozonation treatment was better than continuous ozonation treatment 
for further detoxification and maintaining the total microbial activity of soil microorganisms.

Acknowledgments The work was supported by the Doctoral Fund of Ministry of Education of the People's Republic of China (No. 20124433120021) and the Research Start-up Fund of Southern Medical University (No. B1000351).

\section{Nomenclature}

$\begin{array}{ll}\text { PAHs } & \text { Polycyclic aromatic hydrocarbons } \\ \text { Phe } & \text { Phenanthrene } \\ \text { Ant } & \text { Anthracene } \\ \text { Flu } & \text { Fluoranthene } \\ \text { Pyr } & \text { Pyrene } \\ \text { BaP } & \text { Benzo(a)pyrene }\end{array}$

\section{References}

Ahn Y, Jung H, Tatavarty R, Choi H, Yang JW, Kim IS (2005) Monitoring of petroleum hydrocarbon degradative potential of indigenous microorganisms in ozonated soil. Biodegradation 16(1):45-56

Choi H, Lim HN, Kim J, Hwang TM, Kang JW (2002) Transport characteristics of gas phase ozone in unsaturated porous media for in situ chemical oxidation. J Contam Hydrol 57(1-2):81-98

Derudi M, Venturini G, Lombardi G, Nano G, Rota R (2007) Biodegradation combined with ozone for the remediation of contaminated soils. Eur J Soil Biol 43(5-6):297-303

Eberius M, Berns A, Schuphan I (1997) Ozonation of pyrene and benzo[a]pyrene in silica and soil $-{ }^{14} \mathrm{C}$-mass balances and chemical analysis of oxidation products as a first step to ecotoxicological evaluation. Fresenius J Anal Chem 359(3):274-279

El Diwani G, El Rafie S, Hawash S (2009) Degradation of 2, 4, 6-trinitotoluene in aqueous solution by ozonation and multi-stage ozonation biological treatment. Int $\mathrm{J}$ Environ Sci Technol 6(4):619-628

Gee GW, Bauder JW (1986) Particle-size analysis. In: Klute A (ed) Methods of soil analysis, Part I. Physical and mineralogical methods, 2nd edn. American Society of Agronomy, Madison, pp 383-411

Gharbani P, Khosravi M, Tabatabaii SM, Zare K, Dastmalchi S, Mehrizad A (2010) Degradation of trace aqueous 4-chloro-2nitrophenol occurring in pharmaceutical industrial wastewater by ozone. Int J Environ Sci Technol 7(2):377-384

Giri RR, Ozaki H, Taniguchi S, Takanami R (2008) Photocatalytic ozonation of 2, 4-dichlorophenoxyacetic acid in water with a new $\mathrm{TiO}_{2}$ fiber. Int J Environ Sci Technol 5(1):17-26

Goi A, Trapido M (2004) Degradation of polycyclic aromatic hydrocarbons in soil: the Fenton reagent versus ozonation. Environ Technol 25(2):155-164

Goi A, Kulik N, Trapido M (2006) Combined chemical and biological treatment of oil contaminated soil. Chemosphere 63(10):1754-1763

Haapea P, Tuhkanen T (2006) Integrated treatment of PAH contaminated soil by soil washing, ozonation and biological treatment. J Hazard Mater 136(2):244-250

Haritash AK, Kaushik CP (2009) Biodegradation aspects of polycyclic aromatic hydrocarbons (PAHs): a review. J Hazard Mater 169(1-3):1-15

Hong PKA, Nakra S, Kao JCM, Hayes DF (2008) Pressure-assisted ozonation of PCB and PAH contaminated sediments. Chemosphere 72(11):1757-1764
Hsu MI, Masten SJ (1997) The kinetics of the reaction of ozone with phenanthrene in unsaturated soils. Environ Eng Sci 14(4):207-218

Jekel M (2000) Full-scale applications. In: Gottschalk C, Libra JA, Saupe A (eds) Ozonation of water and waste water: a practical guide to understanding ozone and its application. Wiley-VCH, Weinheim, pp 21-36

Jung H, Choi H (2003) Effects of in situ ozonation on structural change of soil organic matter. Environ Eng Sci 20(4):289-299

Jung H, Ahn Y, Choi H, Kim IS (2005) Effects of in situ ozonation on indigenous microorganisms in diesel contaminated soil: survival and regrowth. Chemosphere 61(7):923-932

Liang Y, Nostrand JD, Wang J, Zhang X, Zhou J, Li G (2009) Microarray-based functional gene analysis of soil microbial communities during ozonation and biodegradation of crude oil. Chemosphere 75(2):193-199

Lopez A, Ricco G, Mascolo G, Tiravanti G, Di Pinto AC, Passion R (1998) Biodegradability enhancement of refractory pollutants by ozonation: a laboratory investigation on an azo-dyes intermediate. Water Sci Technol 38(4-5):239-245

Luster-Teasley S, Ubaka-Blackmoore N, Masten SJ (2009) Evaluation of soil $\mathrm{pH}$ and moisture content on in situ ozonation of pyrene in soils. J Hazard Mater 167(1-3):701-706

Masten SJ, Davies SHR (1997) Efficacy of in situ ozonation for the remediation of PAH contaminated soils. J Contam Hydrol 28(4):327-335

Nam K, Kukor JJ (2000) Combined ozonation and biodegradation for remediation of mixtures of polycyclic aromatic hydrocarbons in soil. Biodegradation 11(1):1-9

Nimmer MA, Wayner BD, Morr AA (2000) In situ ozonation of contaminated groundwater. Environ Prog 19(3):183-196

Rakness K, Gordon G, Langlais B, Masschelein W, Matsumoto N, Richard Y, Robson CM, Somiya I (1996) Guideline for measurement of ozone concentration in the process gas from an ozone generator. Ozone Sci Eng 18(3):209-229

Rivas FJ, Beltrán FJ, Acedo B (2000) Chemical and photochemical degradation of acenaphthylene: intermediate identification. J Hazard Mater 75(1):89-98

Rivas J, Gimeno O, de la Calle RG, Beltrán FJ (2009) Ozone treatment of PAH contaminated soils: operating variables effect. J Hazard Mater 169(1-3):509-515

Russo L, Rizzo L, Belgiorno V (2012) Ozone oxidation and aerobic biodegradation with spent mushroom compost for detoxification and benzo(a)pyrene removal from contaminated soil. Chemosphere 87(6):595-601

Schnürer J, Rosswall T (1982) Fluorescein diacetate hydrolysis as a measure of total microbial activity in soil and litter. Appl Environ Microbiol 43(6):1256-1261

Sung M, Lee SZ, Huang CP (2008) Ozonation of pentachlorophenol in unsaturated soils. J Contam Hydrol 98(3-4):75-84

Wu J, Jiang Y, Zha L, Ye Z, Zhou Z, Ye J, Zhou H (2010) Tetracycline degradation by ozonation, and evaluation of biodegradability and toxicity of ozonation byproducts. Can $\mathbf{J}$ Civ Eng 37(11):1485-1491

Yao JJ, Huang ZH, Masten SJ (1998a) The ozonation of pyrene: pathway and product identification. Water Res 32(10):3001-3012

Yao JJ, Huang ZH, Masten SJ (1998b) The ozonation of benz(a)anthracene: pathway and product identification. Water Res 32(11):3235-3244

Yu D, Bae W, Kang N, Banks MK, Choi C (2005) Characterization of gaseous ozone decomposition in soil. Soil Sediment Contam 14(3):231-247

Zeng Y, Hong PKA, Wavrek DA (2000) Chemical-biological treatment of pyrene. Water Res 34(4):1157-1172 